\title{
İnternet mühitdə "yırtıcı" jurnalların avtomatik tanınması üçün intellektual sistemin yaradılmasının konseptual əsasları haqqinda
}

\author{
Rəhilə Həsənova ${ }^{1}$, Firudin Әsgərov $^{2}$ \\ ${ }^{1,2}$ AMEA İnformasiya Texnologiyaları İnstitutu, Bak1, Azərbaycan \\ ${ }^{1}$ rahasanova@gmail.com, ${ }^{2}$ firudinasgarovegmail.com
}

\begin{abstract}
Xülasə - Bu məqalədə yırtıcı jurnalları avtomatik təyin edən antiyırtıcı sistemin iş prinsipi təhlil edilmişdir. Antiyırtıcı sistemin blok sxemlərlə sadə ifadəsi təqdim edilmişdir.
\end{abstract}

Açar sözlor — yırtıcı jurnal; yırtıcı noşriyyat; impakt faktor

\section{GIRIS}

"Yırtıcı jurnallar" ifadəsini ilk dəfə amerikalı kitabxanaçı, Kolorado Denver Universitetinin dosenti Cefri Bill istifadə etmişdir. O, bu cür jurnalları 2008-ci ildən etibarən analiz etməyə başlamışdır. Buna səbəb isə ona jurnalların elektron ünvanlarından redaksiya heyətinə dəvət haqqında külli miqdarda şübhəli elektron məktubların gəlməsi idi. $\mathrm{Bu}$ məktubların içərisində çoxsaylı qrammatik səhvlərin mövcudluğu onun diqqətini çəkmişdi. Həmin vaxtdan etibarən o, mütəmadi olaraq yenilənən, böyük ehtimalla "yırtıcı" hesab olunan jurnalların "qara" siyahısını hazırlamağa başladı. Burada jurnalların Scopus və Web of Science kimi beynəlxalq akademik bazalar tərəfindən "ağ" və ya "qara" siyahiya daxil olması yoxlanılır, onların bazada qalması və ya çıxarılması haqqinda qərar qəbul edilir [1-5].

Son 10 ildə dünyada aktual olan yırtıcı jurnallarda məqalə dərci artıq Azərbaycanda da müzakirə mövzusudur. Belə ki, elmi müəssisələrdə tədqiqatçıların bilərəkdən və yaxud təsadüfən yırtıcı jurnallarda məqalə çap etdirməsi tədqiqatçı ilə yanaşı həmin müəssisənin nüfuzuna da xələl gətirmiş olur. $\mathrm{Bu}$ baxımdan müəllifin orijinal və yırtıcı jurnalları xarakterizə edən xüsusiyyətləri bilməsi vacibdir.

Azərbaycanda yırtıcı jurnal və nəşriyyatları xarakterizə edən göstəricilər haqqında məlumatsızlıq elmi müəssisələri, elmi tədqiqatçıları yırtıcı və ya oğurlanmış jurnallarla qarşılaşma təhlükəsi ilə üz-üzə qoyur.

Araşdırmalar onu göstərir ki, bu gün yırtıcı jurnallar təhlükəsindən qorunmaq məqsədi ilə antiyırtıcı sistemin işlənməsi zəruridir. Təcrübə göstərir ki, müxtəlif ölkələrdə bu məsələ ilə bağlı bəzi işlər görülməyə başlanmışdır. Məsələn, 2015-ci ildən fəaliyyət göstərən Düşün! - Yoxla! - Təqdim et! (Think! - Check! - Submit!) onlayn sistemi bu baxımdan maraq kəsb edir [7].

\section{MəQALӘ DəRCI ÜÇÜN DÜZGÜN JURNAL SEÇIN DÜŞÜN! - YOXLA! - TəQDIM ET!}

Dünyada artıq 33 dildə fəaliyyət göstərən thinkchecksubmit.org saytı tədqiqatçılara məqalə dərc etdirmək üçün düzgün jurnal seçməkdə kömək edir. Bu saytın məqsədi müəllifə birinci mərhələdə düşünməyi, ikinci mərhələdə yoxlamağı, sonda isə məqaləni təqdim etməyi məsləhət görür [7].

Birinci - Düşün! (Think!) mərhələsində tədqiqatçı aşağıdakı suallara cavab tapır:

- Elmi tədqiqatınızı dərc etdirmək üçün etibarlı jurnal seçmisinizmi?

- Bu jurnal sizin tədqiqat sahənizə tam uyğundurmu?

$\mathrm{Bu}$ suallar tədqiqatçıya seçilən jurnalın doğru jurnal olduğuna əmin olmaq məqsədilə verilir.Çünki dünyada nəşrlərin sayı getdikcə artır, demək olar ki, hər həftə yeni jurnallar fəaliyyətə başlayır. "Yırtıcı" nəşriyyatların qanuna zidd hərəkətləri və aldatma halları da getdikcə artmaqdadır və məqalə dərc etdirmək üçün etibarlı jurnal tapmaq günü-gündən çətinləşir.

İkinci - Yoxla! (Check!) mərhələsində tədqiqatçının seçdiyi jurnalın etibarlı olub-olmadığı yoxlanılır. Bu məqsədlə aşağıdakı suallar cavablandırılmalıdır:

- Siz və ya həmkarınız bu jurnalı tanıyırsınızmı?

$\checkmark$ Әvvəllər həmin jurnaldan hər hansı bir məqalə oxumusunuzmu?

$\checkmark$ Jurnalda ən son dərc edilmiş məqalələri əldə etmək mümkündürmü?

- Nəşriyyat1 müəyyənləşdirmək və əlaqə yaratmaq mümkündürmü?

$\checkmark$ Nəşriyyatın adı jurnalın veb saytında əks olunurmu?

$\checkmark$ Nəşriyyatla saytda əks olunmuş telefon nömrəsi, poçt və elektron poçt ünvanı ilə əlaqə yaratmaq mümkündürmü?

- Jurnalın istifadə etdiyi qiymətləndirmə növü (rəy, resenziya) şəffafdırmı? 


\section{“Informasiya tohlükosizliyinin aktual multidissiplinar elmi-praktiki problemlori” IV respublika konfransı, 14 dekabr 2018-ci il}

- Jurnalın məqalələri saytında adı çəkilmiş beynəlxalq bazalarda həqiqətən indekslənirmi?

- Ödəniş haqqında məlumatları jurnalın saytında əldə etmok mümkündürmü?

$\checkmark$ Jurnalın saytında ödənişin nə üçün tələb olunduğu izah olunurmu?

$\checkmark$ Ödənişin nə zaman həyata keçirilməsi haqqında molumat verilirmi?

- Redaksiya heyətinin üzvləri sizə tanış alimlərdir?

$\checkmark$ Redaksiya heyətinin üzvləri haqqında eşitmisinizmi?

$\checkmark$ Redaksiya heyəti üzvləri öz veb saytlarında bu jurnalın adını qeyd edirlərmi?

- Jurnalın nəşriyyatı beynəlxalq elmi cəmiyyətlərin üzvüdürmü?

$\checkmark$ Jurnalın nəşriyyatı COPE (Committee on Publication Ethics)-in üzvüdürmü?

$\checkmark$ Jurnal açıq əlyetərdirsə, onun adı DOAJ (Directory of Open Access Journals)-1n siyahisinda varmı?

$\checkmark$ Jurnal açıq əlyetərdirsə, onun adı OASPA (Open Access Scholarly Publishers' Association)-nın siyahısında varmı?

$\checkmark$ Jurnal INASP's Journals Online vo ya African Journals Online platformalarından hər hansı birinə daxildirmi?

$\checkmark$ Nəşriyyat hər hansı digər ticarət assosiasiyasına daxildirmi?

Üçüncü - Təqdim et! (Submit!) mərhələsində əvvəlki mərhələdə sadalanan sualların hamısı və ya əksəriyyətinin cavabı müsbətdirsə, onda tədqiqatçıya məqaləsini həmin jurnala təqdim etmək məsləhət görülür. Lakin bu mərhələdə də diqqət yetirilməli bir neçə əsas məqam vardır:

- Burada əmin olmaq lazımdir ki, məqalənin təqdim olunduğu jurnal tədqiqatçının həmkarları arasında reputasiyasını qaldırmağa və çoxlu istinadlar qazanmağa səbəb olacaqdir.;

- Məqaləni doğru jurnalda dərc etməklə tədqiqatçı karyerasını inkişaf etdirə və profesional imicini yüksəldə bilər.;

- Məqalə dərc olunduqdan sonra bazalarda indekslənəcək və axtarış sistemlərində asanlıqla tapılacaqdır.

Məqalənin yoxlanma və dərci müddətində nəşriyyatın peşəkar təcrübəsi özünü göstərməlidir.

\section{ANTIYIRTICI SISTEMIN BLOKLARININ IZAHI}

Düşün! - Yoxla! - Təqdim et! və digər təcrübələrə əsaslanaraq antiyırtıcı sistemin konsepsiyası işlənmişdir [6,7]. $\mathrm{Bu}$ antiyırtıcı sistemin işləmə mexanizmi Şəkil 1-də bloksxemlər vasitəsilə təsvir edilir. İlk mərhələ jurnalın adının axtarış sisteminə daxil edilməsi ilə başlayır. Sonra hər bir addımda jurnala aid müəyyən məntiqi suallar "hə" və ya "yox" ilə cavablandırılaraq növbəti mərhələyə keçid alır. Mürəkkəb budaqlanan struktura malik bu alqoritmin nəticəsində jurnalın orijinal və yaxud da yırtıcı olması ehtimalı irəli sürülür.

Hər bir məntiqi blokda verilmiş sualın hansı xüssusiyyətləri əks etdirməsi * işarəsi ilə şərh edilir.

*Burada saytın jurnalın həqiqi saytı olduğunu müəyyənləşdirmək nəzərdə tutulur. Bir neçə əsas məqama nəzər yetirmək lazım gəlir: 1. Jurnalın saytının onun dərc edildiyi ölkənin domen zolağına aid olması; 2. Verilmiș saytın jurnalın oğurlanmış versiyasına aid olması (əgər mövcuddursa); 3. Redaksiya heyəti ilə əlaqə məlumatlarının dolğunluğu (redaksiyanın ünvanı, əlaqə nömrələri, e-mail və s.); 4. Nəşrlərin dövriliyinin gözlənilməsi, yəni hər il eyni sayda nömrələrin dərc edilməsi (Issue); 5. Saytın görünüşünün vizual qiymətləndirilməsi. Bu zaman saytın konstruktor sayt olub-olmaması yoxlanılır və pulsuz domen və subdomenlərdə yerləşməsi araşdırılır; 6. Saytın alt səhifələrinin mövcudluğu və aktivliyi; 7. Saytda verilmiş məlumatların qrammatika və orfoqrafiya baxımından düzgün yazılması.

**Jurnalın akademik bazalarda indeksləşməsi haqqında saytda verilmiş məlumatın (məs., impakt faktor göstəricisi) həqiqi olub-olması müəyyənləşdirilir, bu məlumatda hiperkeçidin olması onun doğruluğunu göstərir.

***Burada əsasən aşağıdakı məlumatlar yoxlanılır: 1 Jurnalın redaktorunun nəşr olunduğu nəşriyyatın rəhbəri ilə eyni şəxs olub-olmaması (adətən nəşriyyat rəhbəri özünü bir və ya bir neçə jurnalın baş redaktoru kimi qeyd edir). 2. Redaksiya üzvləri haqqında akademik məlumatların mövcudluğu; 3. Eyni nəşriyyat tərəfindən dərc edilən bir və ya bir neçə jurnalın redaksiya heyətinin tərkiblərinin eyniliyi; 4. Redaksiya heyəti üzvlərinin sayının kifayət qədər olmaması (bəzən, qeyd olunan redaksiya heyəti üzvünün adının siyahıda olmasından xəbərsiz olmas1); 5. Jurnal beynəlxalq olduğunu iddia etdiyi halda onun redaksiya heyəti üzvlərinin beynəlxalq müxtəlifliyi cüzi və ya heç olmaması; 6 . Redaksiya heyəti üzvlərinin gender bərabərsizliyi (çox vaxt qadın üzvləri olmur).

****Tamlıq xassəsi dedikdə aşağıdakılar nəzərdə tutulur: 1. Jurnalın adının onun missiyasını əks etdirməsi; 2. Jurnalın adında istifadə olunan ölkə adlarının həqiqəti əks etdirməsi (məsələn, bəzən Kanada, İsveçrə və s. kimi ölkə adları jurnalın adında istifadə olunmasına baxmayaraq, nə nəşriyyatın, nə redaksiya heyətinin bu ölkələrə aidiyyatı olmur); 3. Nəşriyyat göndərdiyi spam məktublarında və ya öz saytında impakt faktor və beynəlxalq bazalarda indekslənmə haqqinda məlumatın verilməsi. Burada iddia edilir ki, nəşriyyatın dərc etdiyi jurnalların bir neçəsi impakt faktora malikdir (Thomson Reuters) və ya saxta təşkilatlardan əldə edilən impakt faktorlar reklam edilir.

*****Burada aşağıdakı məlumatlar yoxlanılır: 1. Nəşriyyat tərəfindən məqalənin əvvəllər digər jurnallarda dərc edildiyi yoxlanırmı? 2. Dərc edilmiş məqalələr yalançı elmə (pseudoscience) aiddir. 3. Olaqə hissəsində sadəcə e-mail və yaxud da veb forum qeyd edilir. Bununla da nəşriyyat əsas ünvanını gizli saxlamış olur. 
******Burada isə aşağıdakı məqamlar araşdırılır: 1. Nəşriyyatın digər nəşriyyatların müəlliflərə qoyduğu tələbləri eynilə öz tələbi kimi qeyd etməsi. 2. Nəşriyyatda jurnalların adının ümumi verilməsi ilə çoxlu sayda məqalə toplanmasına və müəlliflərdən daha çox gəlirin əldə edilməsinə nail olmaq. Məsələn, Təhsil jurnalı (Journal of Education). 3. Bir-biri ilə əlaqəsi olmayan 2 və daha çox elm sahələrini əhatə edən jurnalların nəşr edilməsi. Məsələn, Biznes, Humanitar və Texnologiya beynolxalq jurnalı (International journal of Business, Humanities and Technology). 4. Nəşriyyat tərəfindən jurnalların saytının zəif hazırlanması, ölü hiperkeçidlər (dead links), çoxlu sayda orfoqrafik və qrammatik səhvlərin mövcudluğu. 5. Saytlarda müəlliflərə istinad edilmədən lisenziyalı şəkillərin istifadəsi.

\section{NəTICӘ}

Elmi jurnalların sürətlə artdığı bu dövrdə orijinal və yırtıcı jurnalların avtomatik müəyyənləşdirmək ehtiyacı yaranır. Bunun üçün ilk növbədə akademik cəmiyyətdə elmi jurnalların "ağ siyahı"sı və "qara siyahı"sı haqqında açıq məlumatların olması vacib məsələlərdəndir. Bundan başqa tədqiqatçının öz araşdırması nəticəsində məqaləsini dərc etdirmək üçün seçdiyi jurnalın orijinal və yaxud yırtıcı olması müəyyən oluna bilər. Lakin bu prosesin avtomatlaşdırılması o baxımdan aktualdır ki, tədqiqatçının yırtıcı jurnalı təyin etməyə vaxtı və əməyi sərf olunmayacaq.

\section{İSTINADLAR}

[1] Beall J. Predatory publishing is just one of the consequences of gold open access // Learned Publishing, 2013, vol.26, no.2, pp.79-83.

[2] Beall J. Predatory publishers are corrupting open access // Nature, 2012, vol.489, no.7415, http://www.nature.com/news/predatory-publishersare-corrupting-open-access-1.11385.

[3] Beall J. Essential information about predatory publishers and journals. International Higher Education, 2016, http://www.ejournals.bc.edu /ojs/index.php/ihe/article

[4] Hijacked Journals, http://www.beallslist.weebly.com/hijackedjournals.html

[5] Həsənova R.Ş., Osgərov F.Ş. "Yırtıcı" jurnalları xarakterizə edən xüsusiyyətlərin identifikasiyası // İnformasiya cəmiyyəti problemləri, 2018, №2, 97-106 s.

[6] Laine Ch., Winker M.A. Identifying Predatory or Pseudo-Journals // Biochemia Medica, 2017, vol.27, no 2, pp.285-291.

[7] thinkchecksubmit.org

\section{A CONCEPTUAL MODEL OF CREATING AN ANTI- PREDATORY SYSTEM FOR IDENTIFICATION OF "PREDATORY" JOURNALS}

Rahila Hasanova ${ }^{1}$, Firudin Asgarov ${ }^{2}$

${ }^{1,2}$ Institute of Information Technology of ANAS,

$$
\text { Baku, Azerbaijan }
$$

Astract - This article analyzes the working principle of the antipredatory system, which automatically identifies predatory journals. The simplest expression of the anti-predatory system with block diagrams is presented.

Keywords - predatory journal; predatory publishing; impact factor 


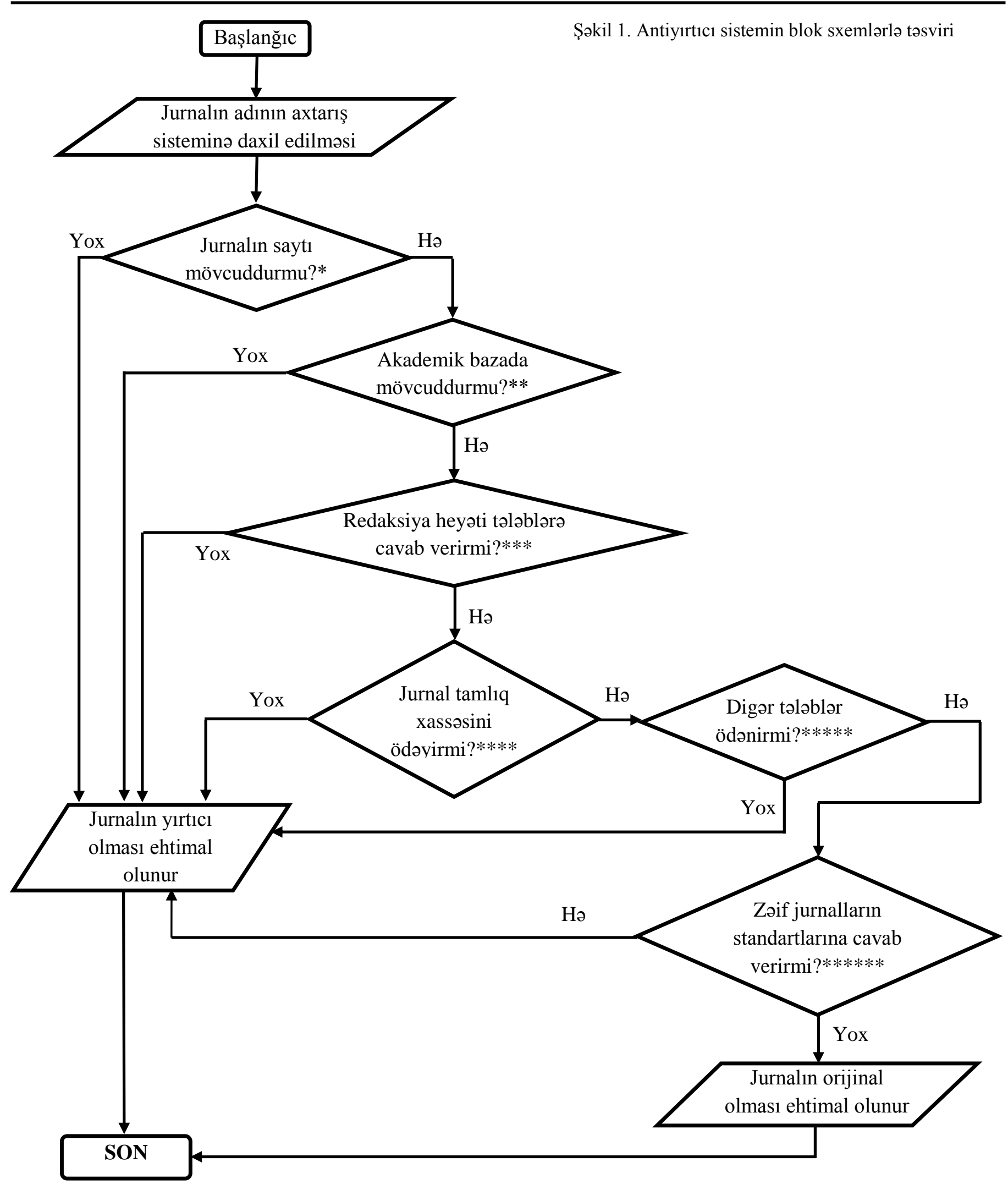

